\title{
Mitigation of methane emissions in a pilot-scale biocover system at the AV Miljø Landfill, Denmark: 1. System design and gas distribution
}

\author{
Cassini, Filippo; Scheutz, Charlotte; Skov, Bent Henning; Mou, Zishen; Kjeldsen, Peter
}

Published in:

Waste Management

Link to article, DOI:

10.1016/j.wasman.2017.01.013

Publication date:

2017

Document Version

Peer reviewed version

Link back to DTU Orbit

Citation (APA):

Cassini, F., Scheutz, C., Skov, B. H., Mou, Z., \& Kjeldsen, P. (2017). Mitigation of methane emissions in a pilotscale biocover system at the AV Miljø Landfill, Denmark: 1 . System design and gas distribution. Waste Management, 63, 213-225. https://doi.org/10.1016/j.wasman.2017.01.013

\section{General rights}

Copyright and moral rights for the publications made accessible in the public portal are retained by the authors and/or other copyright owners and it is a condition of accessing publications that users recognise and abide by the legal requirements associated with these rights.

- Users may download and print one copy of any publication from the public portal for the purpose of private study or research.

- You may not further distribute the material or use it for any profit-making activity or commercial gain

- You may freely distribute the URL identifying the publication in the public portal 
Mitigation of methane emissions in a pilot-scale biocover system at the AV Miljø Landfill, Denmark: 1. System design and gas distribution

Filippo Cassini, Charlotte Scheutz, Bent H. Skov, Mou Zishen, Peter Kjeldsen

Department of Environmental Engineering, Technical University of Denmark, DK-2800 Kgs. Lyngby, Denmark

\begin{abstract}
Greenhouse gas mitigation at landfills by methane oxidation in engineered biocover systems is believed to be a cost effective technology, but so far a full quantitative evaluation of the efficiency of the technology in full scale has only been carried out in a few cases. A third generation semi-passive biocover system was constructed at the AV Miljø Landfill, Denmark. The biocover system was fed by landfill gas pumped out of three leachate collection wells. An innovative gas distribution system was used to overcome the commonly observed surface emission hot spot areas resulting from an uneven gas distribution to the active methane oxidation layer, leading to areas with methane overloading. Performed screening of methane and carbon dioxide surface concentrations, as well as flux measurement using a flux chamber at the surface of the biocover, showed homogenous distributions indicating an even gas distribution. This was supported by results from a tracer gas test where the compound HFC-134a was added to the gas inlet over an adequately long time period to obtain tracer gas stationarity in the whole biocover system. Studies of the tracer gas movement within the biocover system showed a very even gas distribution in gas probes installed in the gas distribution layer. Also the flux of tracer gas out of the biocover surface, as measured by flux chamber technique, showed a spatially even distribution.

Installed probes logging the temperature and moisture content of the methane oxidation layer at different depths showed elevated temperatures in the layer with temperature differences to the ambient temperature in the range of $25-50^{\circ} \mathrm{C}$ at the deepest measuring point due to the microbial processes occurring in the layer. The moisture measurements showed that infiltrating precipitation was efficiently drained away from the methane oxidation layer.
\end{abstract}


Keywords: methane oxidation, greenhouse gas, waste disposal, engineered solutions

\section{Introduction}

Landfills containing organic waste produce biogas containing methane $\left(\mathrm{CH}_{4}\right)$. Landfills are significant sources of $\mathrm{CH}_{4}$, which contributes to climate change (Bogner et al., 2008). At some landfills utilization of landfill gas (LFG) is not or cannot be carried out, and the gas is either flared with risk of producing toxic combustion products or just emitted to atmosphere. As an alternative to mitigation by gas utilization systems, mitigation systems based on $\mathrm{CH}_{4}$ oxidation processes may be implemented. Such systems, here called biocover systems are based on microbial $\mathrm{CH}_{4}$ oxidation in full surface biocovers, biowindow systems or open or closed bed biofilter systems. Experiments have documented that very high $\mathrm{CH}_{4}$ oxidation rates can be obtained in biocovers, high enough to significantly reduce the $\mathrm{CH}_{4}$ emission from the landfill (Scheutz et al., 2009). Documentation of the efficiency of biocovers has so far only been carried out in full scale in a few cases. An example is the study carried out at Fakse Landfill, Denmark where a new-developed protocol for biocover system establishment and monitoring was presented (Scheutz et al., 2011a, b) and the second generation biocover system established at the Klintholm Landfill, Denmark (Scheutz et al., 2014, Kjeldsen et al., 2009). Both mentioned biocover systems were passively loaded with landfill gas from the landfilled waste. One of the lessons learned from these two fullscale biocover systems was that avoidance of point releases of $\mathrm{CH}_{4}$ from the leachate collection system was very difficult to achieve. In addition, a major challenge in any biocover system is to obtain an even gas distribution to the active $\mathrm{CH}_{4}$ oxidation layer to avoid areas with $\mathrm{CH}_{4}$ overloading, which results in hot spots with significant $\mathrm{CH}_{4}$ emissions. Hot spot areas with elevated local $\mathrm{CH}_{4}$ emissions were observed both at the biowindows of the Faxe biocover system, and also to a lesser extent at the Klintholm biocover system. At the Faxe biocover system detailed studies on one of the biowindows showed large spatial variation in surface $\mathrm{CH}_{4}$ emission on the biowindow surface with values in the order of $1200 \mathrm{CH}_{4} \mathrm{~m}^{-2} \mathrm{~d}^{-1}$ at the edge of the biowindow decreasing to non-detect 3.3 meter away (Pedersen, 2010). Similar detailed studies performed on three biocover sections at the Klintholm biocover system showed only large spatial variation in the surface $\mathrm{CH}_{4}$ emissions from one of the sections with values in the order of $40-60 \mathrm{CH}_{4} \mathrm{~m}^{-2} \mathrm{~d}^{-1}$ at the edge of the biowindow 
decreasing to non-detect 2.5 meter away (Scheutz et al., 2014). Spatial variation in surface emissions were also observed at a biocover system established in the Netherlands (Geck et al., 2012).

At many landfills, a significant fraction of the landfill gas generated may escape from point sources such as leachate collection/inspection wells or installed gas vents (Scheutz et al., 2011a, Fredenslund et al., 2010). In such case semi-passive gas routing systems may be needed with extraction of gas from the identified point source followed by loading of the gas to biofilters for microbial $\mathrm{CH}_{4}$ oxidation. Similar cases could evolve at landfills where the energy utilization of gas loaded from an existing gas extraction system no longer is economical viable; here the energy utilizing facility (such as a gas engine) may be replaced by an actively or passively loaded biofilter to reduce the $\mathrm{CH}_{4}$ emission from the landfill (Kjeldsen and Scheutz, 2014). There is very little full scale experience with biocover systems loaded by point gas releases or existing gas extraction systems. However, Roncato and Cabral (2012) presented pilot-scale field experiments where biofilters were passively loaded from a landfill gas well.

The objective of this study was to design and construct a pilot-scale biocover system loaded with landfill gas collected from leachate collection wells. Special emphasis was given to the gas distribution system, which included a novel design idea intended to obtain an evenly distributed gas load to the $\mathrm{CH}_{4}$ oxidation layer. The functioning of the constructed gas distribution system was assessed by performing surface screens, gas composition evaluations and tracer gas release experiments.

This paper is the first in a series of two. The second paper presents and compares several methodologies for documenting the $\mathrm{CH}_{4}$ oxidation efficiency of the biocover system (Scheutz et al., 2017).

\section{Site characterization and pre-investigations}

\subsection{The landfill site}

AV Miljø is a modern waste disposal site situated in Avedøre Holme, approx. $10 \mathrm{~km}$ South of Copenhagen, Denmark. The disposal site was established in 1989 and has a total disposal capacity of 2 mill. $\mathrm{m}^{3}$ divided into 22 disposal cells. The landfill receives waste from approx. 1.2 mill. inhabitants and 80,000 larger and 
smaller enterprises. Since 1997, it has been forbidden in Denmark to use landfills for disposal of combustible waste. AV Miljø therefore mostly accepts non-combustible waste, i.e., waste with low organic content such as, e.g., shredder waste, asbestos waste, contaminated soils, construction waste, residues from street cleaning, slag and fly ashes from waste incineration. Previous studies have shown that significant quantities of landfill gas are produced at the landfill, where a considerable amount is emitted from the leachate collection system via inspection and collection wells, (Scheutz et al., 2011c, Fredenslund et al., 2010). The planned study and establishment of the pilot scale biocover system focused on the western part of the landfill where several leachate wells showed significant gas emission (see Fig. 1b).

\subsection{Gas flow rates from leachate collection wells}

Pump tests were carried out in six leachate inspection/collection wells in the western part of the landfill. Each test had a duration of about three days where gas was extracted from the well at a gas pump rate of $47 \mathrm{~L}$ $\min ^{-1}$. The accumulative pumped volume was monitored by a gas meter and the content of $\mathrm{CH}_{4}$ was measured continuously by a Photoacoustic Multi Gas Monitor INNOVA 1412i (LumaSense Technologies, Denmark). The results showed that especially three out of the six wells could maintain a significant and constant $\mathrm{CH}_{4}$ supply. The total extracted $\mathrm{CH}_{4}$ from the three wells was calculated to be $26 \mathrm{~kg} \mathrm{CH}_{4} \mathrm{~d}^{-1}$. The three wells were chosen as gas supply wells for the biocover system. Locations of the wells are shown in Fig. $1 \mathrm{~b}$ and c.

\subsection{Testing $\mathrm{CH}_{4}$ oxidation capacities of compost}

Early in the project it was decided to use locally produced compost as bio-active material in the biocover system. Two producers of garden waste compost were identified in the vicinity of the AV Miljø landfill, (Solum and RGS90). Representative sampling of the two compost types was carried out and regular batch incubation test were performed to measure the respiration activity and the $\mathrm{CH}_{4}$ oxidation capability of the two composts. The tests were carried out in $500 \mathrm{~mL}$ containers each containing $100 \mathrm{~g}$ of moist compost. For the respiration tests $120 \mathrm{~mL}$ of the head space air was exchanged with pure oxygen $\left(\mathrm{O}_{2}\right)$ and the decrease of $\mathrm{O}_{2}$ and increase of carbon dioxide $\left(\mathrm{CO}_{2}\right)$ contained in the head space was monitored over a period of 250 hours. For the $\mathrm{CH}_{4}$ oxidation similar tests were set up. Here $30 \mathrm{~g}$ of moist compost was used and $200 \mathrm{~mL}$ of the head space air was 
exchanged with $120 \mathrm{~mL} \mathrm{O}_{2}$ and $80 \mathrm{~mL} \mathrm{CH}_{4}$ followed by monitoring of the gas composition of the head space for 100 hours. More details of material and methods are given in Scheutz et al. (2014).

The results of the batch incubation tests showed that the compost from RGS90 had the lowest respiration (8.9-9.2 $\mu \mathrm{g} \mathrm{O}_{2} \mathrm{~g}^{-1} \mathrm{~h}^{-1}$ ) and also the highest $\mathrm{CH}_{4}$ oxidation rate (126-135 $\left.\mu \mathrm{g} \mathrm{CH}_{4} \mathrm{~g}^{-1} \mathrm{~h}^{-1}\right)$, so the compost from RGS90 was chosen as the active $\mathrm{CH}_{4}$ oxidation medium for the biocover system. Furthermore, the compost was produced very close to the AV Miljø Landfill. Based on previous experiences from the Fakse and Klintholm biocover systems (Scheutz et al., 2011a, Scheutz et al., 2014), where both batch incubations, column experiments and in situ determination of $\mathrm{CH}_{4}$ oxidation capacities of compost layers were carried out, a conservative expected in situ $\mathrm{CH}_{4}$ oxidation capacity of the RGS90 compost was evaluated to be in the vicinity of $50 \mathrm{~g} \mathrm{CH}_{4} \mathrm{~m}^{-2} \mathrm{~d}^{-1}$ based on reviews given by Scheutz et al. (2009) and Sadasivam and Reddy (2014). With an expected $\mathrm{CH}_{4}$ load extracted from the three selected supply wells of $26 \mathrm{~kg} \mathrm{CH}_{4} \mathrm{~d}^{-1}$, the area of the pilot scale biocover system was set to $500 \mathrm{~m}^{2}$.

\section{Overview of the installed biocover system}

The biocover system $(12 \mathrm{~m} \times 42 \mathrm{~m})$ consisted of a gas distribution layer $(30-50 \mathrm{~cm})$ overlain by a compost layer $(80-90 \mathrm{~cm})$ (see Fig. 2). The three supply wells mentioned above were connected with underground piping to an inlet mixing chamber where gas from the three wells was efficiently mixed before being fed to the biocover gas distribution layer (see Fig. 1c). The three landfill gas emitting leachate wells were enclosed in air tight sheds to improve gas extraction. To obtain a controlled loading to the biocover, the landfill gas was pumped from the enclosed wells to the inlet mixing chamber of the biocover. The pumped gas, reached the inlet mixing chamber through three PVC pipes (120 mm diameter). The cylindrical mixing chamber had an internal diameter of $100 \mathrm{~cm}$, and was made of HDPE material. Pumping rates from each of the three sheds were continuously monitored and the content of $\mathrm{CH}_{4}$ in the mixing chamber was continuously monitored with a $\mathrm{CH}_{4}$ sensor and data logger (details provided in section 4.1). Knowing the gas flow and the $\mathrm{CH}_{4}$ content in the mixing chamber, the $\mathrm{CH}_{4}$ load to the biocover could be determined. Other gases $\left(\mathrm{O}_{2}, \mathrm{CO}_{2}\right.$ and nitrogen $\left.\left(\mathrm{N}_{2}\right)\right)$ were 
monitored manually by connecting a gas analysing device to sampling gas tubes connected to the interior of the mixing chamber (more details can be found in section 4.1).

In earlier studies, accumulation of infiltrating water in the interface between the $\mathrm{CH}_{4}$ oxidation layer and gas distribution layer has been identified as a major problem leading to an uneven gas distribution forming $\mathrm{CH}_{4}$ emission hotspots in the biocover surface (Scheutz et al., 2011a, Gebert \& Gröngröft, 2012, Tetreault \& Cabral, 2013). The latter study showed that a capillary barrier can form due to the higher permeability of the coarse gas distribution layer underneath the compost. This effect can cause accumulation of water in the interface between the two layers. In worst case, accumulation of water in the compost layer can result in anaerobic conditions leading to $\mathrm{CH}_{4}$ generation in the deeper part of the biocover (Scheutz et al., 2009). To hinder water accumulation in the interface due to capillary effects a novel interface design was constructed and tested. The interface between the $\mathrm{CH}_{4}$ oxidation layer (consisting of compost) and the coarse gravel gas distribution layer (consisting of small pebbles with size 8-16 $\mathrm{mm}$ ) was "zig-zag-shaped" to minimize continuous water locking due to capillary effects ( Figure 3.1a). The "zig-zag shaped" surface of the gas distribution layer was constructed manually using shovels and was finalized for the $500 \mathrm{~m}^{2}$ biofilter in a few days.

The idea of the zig-zag shaped interface is to construct small capillary barriers leading infiltrating water laterally to the low points. Here the water will temporarily accumulate, but due to the pressure build up, the water will break the capillary barrier and quickly be transported vertically into the coarse gas distribution layer below. Dimensions of the zig-zag shaped interface were not determined based on physical principles of water flow through unsaturated soils, but more on practical construction related considerations. The gas from the inlet mixing chamber was fed into an un-slotted gas pipe (50 mm internal diameter) and via this distributed to 20 slotted gas pipes (100 mm internal diameter). The un-slotted gas pipe was equipped with small outlet holes to obtain an even gas distribution (see Figure 3.1b and c). At each intersect between the un-slotted gas pipe and a slotted gas pipe two $4 \mathrm{~mm}$ outlet holes were drilled to distribute the gas into the slotted pipe.

A section of the gas distribution layer and the $\mathrm{CH}_{4}$ oxidation layer was equipped with horizontal multiport gas monitoring units to study gas distribution and $\mathrm{CH}_{4}$ oxidation processes (see Material and Methods section 4.5). Two transects each having 50 gas ports were constructed at two different distances from the gas 
inlet (see Figure 3.1b and c). The biogas system was equipped with a water draining system including a water lock to avoid gas by-pass.

The system was constructed in the summer of 2012 with the gas load start up in September 2012. During the experimental period, the biocover was gradually vegetated by different weeds, which at the end of the experimental period reached a height of up to $150 \mathrm{~cm}$. The first year, the vegetation was dominated by one single species of Chenopodium with several species taking over in the second growth season.

\section{Materials \& Methods}

\subsection{Monitoring of gas supply to the biocover}

The gas pumping rate was continuously monitored at each of the air tight sheds confining the leachate wells by occasionally reading the accumulative gas meter (Flonidan, Denmark). The landfill gas composition in the inlet of the biocover was monitored continuously during the whole study period. An OLCT Infrared Transmitter Detector (Oldham, France) was installed in the mixing chamber and the $\mathrm{CH}_{4}$ percentage composition measured every 5 minutes. Data were recorded by using a GP-HR TruTrack outdoor data logger (Intech, New Zealand). Additionally, the major constituents of the gas were monitored in the mixing chamber once a week by using a Biogas 5000 portable gas analyser (Geotech, Warwickshire, UK). $100 \mathrm{~mL}$ of gas was extracted from the three inlet pipes to the mixing chamber and from the inlet pipe to the biofilter distribution system. The volumetric percentage composition of $\mathrm{CH}_{4}, \mathrm{CO}_{2}$, and $\mathrm{O}_{2}$ was determined and manually recorded.

\subsection{Moisture and temperature probes and measurements}

Compost temperature and moisture content were monitored throughout the entire study period. Combined temperature and moisture probes (ECH2O EC-TM probes -Decagon Devices, USA) were installed in three different depths $(-20 \mathrm{~cm},-50 \mathrm{~cm}$, and $-95 \mathrm{~cm})$ in the $\mathrm{CH}_{4}$ oxidation layer of the biocover. For determination of volumetric water content (VWC) a soil-specific calibration was previously done on a similar compost material for the ECH2O-TM probe in accordance with the calibration method specified by the instrument manufacturer (Pedersen, 2010). In this study, gravimetric water contents were compared with measured raw counts and a correlation between raw counts and VWC was found $\left(\mathrm{VWC}=1.006 \cdot 10^{-6} \cdot \mathrm{raw}-0.425, \mathrm{R}^{2}=0.9897\right)$. The 
calibration curve was comparable with the one given in the instrument operators manual (version 5) for several potting soils $\left(\mathrm{VWC}=1.04 \cdot 10^{-6} \cdot \mathrm{raw}-0.5\right)$.

The Decagon TM probe measured temperature by an on board thermistor, along with accurate volumetric water content by measuring the dielectric constant of the compost using capacitance/frequency domain technology. The location of the probes is shown in Fig. 3. A digital EM50 Decagon data logger (Decagon Devices, USA) was connected to the three probes and programmed to measure the temperature $\left({ }^{\circ} \mathrm{C}\right)$ and moisture content $\left(\mathrm{m}^{3} \cdot \mathrm{m}^{-3}\right.$ volumetric water content $\left.(\mathrm{VWC})\right)$ every 5 minutes. The probe in the $-95 \mathrm{~cm}$ depth unfortunately stopped recording moisture after November $7^{\text {th }}, 2012$.

\subsection{Surface screening of $\mathrm{CH}_{4}$ and $\mathrm{CO}_{2}$}

A qualitative analysis of the spatial variability in surface emissions was carried out by measuring the gas concentrations of $\mathrm{CH}_{4}$ and $\mathrm{CO}_{2}$ above ground surface. A grid was created to regularly divide the biocover area in 252 rectangular subareas of $2 \mathrm{~m}^{2}$ each. Surface air concentrations were measured at the central spot of each subarea $10 \mathrm{~cm}$ above the soil surface. Surface $\mathrm{CH}_{4}$ concentrations (ppmv) were measured with a TVA1000B Photovac MicroFID analyzer (ThermoScientific, Waltham, USA) whereas surface $\mathrm{CO}_{2}$ concentrations (ppmv) were measured using a Vaisala CARBOCAP ${ }^{\circledR}$ Infrared Sensor (Vaisala, USA). All the screening campaigns took place during monitored weather conditions with low wind speed and stable barometric pressure to minimize spatial mixing of the sampled gas. A total of six measurement campaigns were carried out during the whole study period. The screening was carried out on November $28^{\text {th }}, 2012$, December $4^{\text {th }}, 2012$, April $11^{\text {th }}, 2013$, April $21^{\text {st }}, 2013$, May $2^{\text {nd }}, 2013$ and May $24^{\text {th }}, 2013$. Collected data were then processed by using Surfer 8 software (Golden Software Inc., Golden, USA) and interpolated with kriging statistical method to define iso-concentration curves.

\subsection{Surface emissions of $\mathrm{CH}_{4}, \mathrm{CO}_{2}$ and tracer gas (HFC-134a)}

The initial surface screening was followed up by quantitative measurements of emissions from the biocover surface. With this methodology, the surface distribution of $\mathrm{CH}_{4}, \mathrm{CO}_{2}$ and tracer gas fluxes was evaluated. A series of 50 points equally distributed over the biocover surface was chosen for gas flux sampling sampling locations are shown in Fig. 3. Surface emission rates were determined using static flux chambers. The 
flux chambers were made of stainless steel, equipped with sampling ports and a manually operated fan securing that the air inside the chamber was totally mixed during sampling. When installed, the flux chamber had a height of approximately $21 \mathrm{~cm}$ and an inner diameter of $30 \mathrm{~cm}$ (giving a total chamber volume of $15 \mathrm{~L}$ ). The emission rates were measured by taking a time series of gas samples ( 1 sample per minute for minimum 5 minutes) from the chambers. A Photoacoustic Multi Gas Monitor INNOVA 1412i (LumaSense Technologies, Denmark) was used to measure concentrations of $\mathrm{CH}_{4}, \mathrm{CO}_{2}$, and tracer gas (HFC-134a) (for the tracer gas only during tracer gas release experiments). Concentrations and times of measurement were logged using a laptop PC connected to the instrument. Measurement ranges at the used configuration of the instrument were $0.4-20,000 \mathrm{ppmv}$ $\left(\mathrm{CH}_{4}\right), 1.5-10,000$ ppmv $\left(\mathrm{CO}_{2}\right)$ and 0.2-2,000 ppmv (HFC-134a). In general, the concentration vs. time curves showed good linear fits $\left(r^{2}>0.9\right)$ without any change in slope for the final sampling times. Fluxes were calculated from the product of the change in concentration over time $(\mathrm{dC} / \mathrm{dt})$ and the chamber volume/chamber area ratio (Scheutz et al., 2003, 2008). The detection limit of the flux chamber measurements were $\pm 0.05 \mathrm{~g} \mathrm{~m}^{-2}$ $d^{-1}$. A spatial two-dimensional distribution of fluxes was obtained by processing calculated fluxes for each measuring day with Surfer 8 software using interpolation by the kriging statistical method.

\subsection{Horizontal multi-port gas probes (HMPGP) - design and sampling}

To evaluate the spatial vertical and horizontal distribution of gas loaded to the biocover, a multi-port gas sampling system was designed. Two transects of 50 ports each were embedded in the biocover; one in the South-Eastern part (3.5 m North of the Southern biocover boundary, called Southern transect) of the biocover and one in the North-Eastern ( $8.5 \mathrm{~m}$ North of the Southern biocover boundary, called Northern transect). Each sampling port was designed to connect a predetermined point inside the biofilter to the outside, in order to make the sampling of the pore gas easier and avoid compaction of the compost layer by walking on the biocover area. In each transect, the ports were divided in five groups, each laid at a different depth in the biocover volume (-20 $\mathrm{cm},-50 \mathrm{~cm},-75 \mathrm{~cm},-100 \mathrm{~cm}$ and $-120 \mathrm{~cm}$ below ground surface). Each depth was labelled with different letters ( $A, B, C, D, E$ ) with A being the shallowest one. In the end, each port of this group of ten was placed at a different distance from the gas inlet point and labelled with a number. The ports were located at 18(\#1), 16(\#2), 
14(\#3), 12(\#4), 11(\#5), 10(\#6), 9(\#7), 8(\#8), 4(\#9), and 2(\#10) meters from the biocover midline, as represented in Fig. 2a. As an example, the port labelled with N1A was located in the North-Eastern part of the biofilter, 18 meters from the biocover midline and at a depth of $20 \mathrm{~cm}$. The exact location (plan view) of each sampling port is also shown in Fig. 3. Each sampling tube had an internal diameter of $2 \mathrm{~mm}$ giving an internal volume of 3.1 $\mathrm{mL} \mathrm{m}{ }^{-1}$. Each bundle of 10 sampling tubes was equipped every second meter with a gas blocking plastic plate to avoid horizontal transport of gas along the bundle.

Gas concentrations of $\mathrm{CH}_{4}, \mathrm{CO}_{2}, \mathrm{O}_{2}$ (volume percentage) were determined using a Biogas 5000 portable gas analyzer (Geotech, Warwickshire, UK). The pump rate of the Biogas 5000 was approximately 550 $\mathrm{mL} / \mathrm{min}$, with an operating temperature range from $-10^{\circ} \mathrm{C}$ to $+50^{\circ} \mathrm{C}$. The pump was set to run for 10 second, with a 30 seconds flushing prior to measurement. The operating range of the gas analyser was between $0-100 \%$ vol. for $\mathrm{CH}_{4}$ and $\mathrm{CO}_{2}$ and $0-25 \%$ vol. for $\mathrm{O}_{2}$. The detection accuracy was $+/-1 \%$ vol. in the concentration range of 0 to $25 \%$ vol. Samples for trace gas quantification (during the tracer gas release experiments - see next section) were analysed using the INNOVA. Data were then processed with Surfer 8 software using interpolation by the kriging statistical method to obtain the vertical two-dimensional distribution of each gas for each of the transects defined by a multi-port sampling system. Data were also used for determination of vertical gas concentration profiles at selected locations.

\subsection{Tracer gas release experiment}

To evaluate the ability of the designed biocover system to evenly distribute the loaded gas to the full footage biocover area and to improve the determination of the biocover efficiency for $\mathrm{CH}_{4}$ oxidation (see Scheutz et al. 2016), a step-input tracer gas test was conducted by injection of a tracer gas into the inlet mixing chamber. The tracer gas adopted for the field study is known scientifically as 1,1,1,2-Tetrafluoroethane or as $\mathrm{C}_{2} \mathrm{H}_{2} \mathrm{~F}_{4}$ (commercially as HFC-134a). The compound is regarded as persistent under anaerobic as well as aerobic conditions (Scheutz et al., 2004, 2007), and has a low hydrophobicity leading to a low retardation due to sorption by the compost material. A 20 L Tedlar gas bag (SKC Inc., Eighty Four, PA, USA) was refilled every $12 \mathrm{~h}$ with pure HFC-134a from a pressurized gas bottle. A constant flux of $0.2 \mathrm{~mL} \mathrm{~s}^{-1}$ was continuously pumped from the gas bag into the inlet mixing chamber with the use of a high-precision peristaltic pump (Masterflex ${ }^{\circledR}$ Digital 
Console Drive, Cole Parmer Instrument Company, Niles, II, USA). A constant flux of tracer gas guaranteed a stable concentration in the inlet of $80 \mathrm{ppmv}$, constantly monitored during the whole experimental period. A ball flow-meter (Porter Instrument Co, INC., Hatfield, PA, USA) was also added between the peristaltic pump and the biocover mixing chamber to guarantee a constant influent tracer gas flux. The INNOVA was calibrated for the analysis of $\mathrm{CH}_{4}, \mathrm{CO}_{2}$ and $\mathrm{C}_{2} \mathrm{H}_{2} \mathrm{~F}_{4}$ altogether, with a detection limit of $3.0 \mathrm{ppmv}, 5.1 \mathrm{ppmv}$ and $200 \mathrm{ppbv}$, respectively. The inlet concentration was measured with the INNOVA twice a day during tracer gas release to ensure a constant flux of tracer gas $\left(68 \mathrm{~g} \mathrm{C}_{2} \mathrm{H}_{2} \mathrm{~F}_{4} \mathrm{~d}^{-1}\right)$ into the biocover system.

A selection of sampling probes in the HMPGP was sampled and tracer gas concentrations determined using the INNOVA during the whole tracer gas study duration. The concentration of tracer gas as a function of time was then plotted to study the tracer gas breakthrough curve at selected ports. A pre-test and two measuring campaigns were carried out using this methodology. The pre-test experiment took place on November $17^{\text {th }}-18^{\text {th }}$, 2012 where gas was extracted from 18 ports ( 9 in the Southern transect and 9 in the Northern transect) over a period of 18 hours. The pre-test made a basis for creating a detailed testing plan for the following two studies. The first tracer gas test was carried out in the period December $5^{\text {th }}-9^{\text {th }}, 2012$ for a total duration of $67 \mathrm{~h}$. During this test, 9 ports in the Southern transect and 9 in the Northern transect were repeatedly monitored using the INNOVA. The ports chosen were \#1, \#4, \#8, respectively 18,12 and 8 meters from the biocover gas inlet. Ports at three depths were tested for each distance $(A, B, D)$ corresponding to $-20 \mathrm{~cm},-50 \mathrm{~cm}$ and $-100 \mathrm{~cm}$ depths below ground surface. The second tracer gas test was performed in the period May $16^{\text {th }}-27^{\text {th }}, 2013$ for a total duration of $262 \mathrm{~h}$. As for the previous tracer gas test, 9 ports were tested for each transect, for a total of 18 ports. Tracer gas concentrations as a function of time were measured for port \#1,\#7,\#10, respectively 18,9 and 2 meters from the biocover inlet. The same three depths $(A, B, D)$ as in the first test were monitored during this campaign. Tracer gas concentrations versus time were plotted to evaluate the tracer gas breakthrough in selected gas probes. At the end of the final tracer gas test, the surface flux of HFC-134a tracer was measured simultaneously with a $\mathrm{CH}_{4}$ and $\mathrm{CO}_{2}$ surface fluxes (as described in section 4.4).

\section{Results \& Discussion}




\subsection{Temperature and moisture conditions in biocover}

Fig. 4 compares precipitation data obtained by the local weather station installed at AV Miljø and the compost moisture data recorded by the probes installed at different depths in the biocover. The comparison of precipitation and compost moisture data showed a correlation between significant rain events and the local increase of the moisture content at all depths. An increasing time delay between a rain event and noticeable compost moisture increase was observed depending on depth (the deeper the biocover depth, the higher the time delay). Between one significant rain event and the following one, a decrease of the moisture content in the $\mathrm{CH}_{4}$ oxidation layer was measured, indicating the ability of the "zig-zag shaped" system to avoid long-lasting accumulation of water in the interface, which may lead to blockage of vertical gas transport. The removal of the exceeding water content from the biofilter system was further handled by the water drainage system installed, which led the excess water to the nearby sewer. In general, the volumetric moisture content increased by depth from around 0.1-0.2 at $20 \mathrm{~cm}$ depth to $0.4-0.5$ at 50-90 $\mathrm{cm}$ depth. However, at no time the moisture content were above 0.6. It should be noticed that we do not know the exact porosity of the compost layers, so we cannot be certain that the lower compost layer was not water-filled for short periods.

Fig. 5 shows the recorded temperatures in three different depths of the biocover over the entire monitoring period. The recorded ambient temperature is also shown. The temperature is a very important environmental factor for microbial $\mathrm{CH}_{4}$ oxidation (Scheutz et al., 2009). The figure shows that significantly elevated temperatures were measured in the biocover. The highest temperatures were observed in the $90 \mathrm{~cm}$ depth with a typical temperature difference to ambient temperature of about $\Delta 50^{\circ} \mathrm{C}$ in the beginning of the period decreasing to about $\Delta 25^{\circ} \mathrm{C}$ in the last period (April - July 2013). Temperatures were generally lower at more shallow depths, but the same trend of decreasing temperature differences over the experimental period $\left(\Delta 30^{\circ} \mathrm{C}\right.$ decreasing to $\Delta 15^{\circ} \mathrm{C}$ for the $50 \mathrm{~cm}$ depth, and $\Delta 10^{\circ} \mathrm{C}$ decreasing to $\Delta 5^{\circ} \mathrm{C}$ for the $20 \mathrm{~cm}$ depth) was observed. The reason to the elevated temperatures can be explained by the oxidation of $\mathrm{CH}_{4}$ and compost respiration (which both are exothermic reactions) in combination with heat transport from below (temperatures in the interior of the landfill have not been measured but is expected to be much higher than normal soil temperatures (Coccia

et al., 2013)). The observed gradually decreasing temperature difference in all three depths of the $\mathrm{CH}_{4}$ oxidation layer is probably due to a lower heat generation from the continuously maturing compost during the ten month 
period. Similar observations were done at the Klintholm biocover system (Scheutz et al., 2014). Further evaluation of the $\mathrm{CH}_{4}$ oxidation and compost respiration process is given in the second article of this series (Scheutz et al., 2017).

\subsection{Gas load to biocover}

The three pumps controlling the gas flow to the inlet mixing chamber gave very constant gas loading of totally $182 \mathrm{~m}^{3} \mathrm{~d}^{-1}$ (data not shown). Fig. 6 shows the $\mathrm{CH}_{4}$ concentration in the mixing chamber for both 2012 and 2013. On the figure the recorded barometric pressure is also shown. The figure shows that the $\mathrm{CH}_{4}$ concentration is fluctuating over time with typical concentrations in the range of $3-12 \%$ vol. The $\mathrm{CH}_{4}$ inlet flux was varying in the same manner due to a constant gas pumping rate. The fluctuations seemed to some extent to be correlated with barometric pressure changes; however there must also be other factors controlling the $\mathrm{CH}_{4}$ content for instance the pressure history some period back in time. As previously demonstrated in other studies (Christophersen and Kjeldsen, 2001; Czepiel et al., 2003; Fredenslund et al., 2010; Kjeldsen and Scheutz, 2011) an inverse correlation can be observed between the $\mathrm{CH}_{4}$ concentration and barometric pressure, identifying changes in barometric pressure as the most significant influencing factor on $\mathrm{CH}_{4}$ emissions from landfill bodies.

As a result of the presented observation it is clear that the $\mathrm{CH}_{4}$ load to the biocover was fluctuating over time. Table 1 shows the manually measured gas composition in the mixing chamber. It is obvious that the leachate collection system had some openings to the atmosphere where atmospheric air was intruding, leading to $\mathrm{O}_{2}$ contents in the gas in the range of $5-13 \%$ vol. The implication of this was, however, that the $\mathrm{CH}_{4}$ oxidation layer was loaded with $\mathrm{O}_{2}$ not only by diffusion from the atmosphere and into the cover, but also due to the $\mathrm{O}_{2}$ content in the loaded gas mixture. Knowing the total pump rate and the $\mathrm{CH}_{4}$ content, the typical $\mathrm{CH}_{4}$ load can be deducted. With an average $\mathrm{CH}_{4}$ content of $10 \%$ vol., the load was $13 \mathrm{~kg} \mathrm{CH}_{4} \mathrm{~d}^{-1}$, which is about $50 \%$ of the initially estimated load $\left(26 \mathrm{~kg} \mathrm{CH}_{4} \mathrm{~d}^{-1}\right)$ from the short time pump test of the three participating leachate wells (see section 2.2). This may be due to a larger dilution in the leachate collection system over the longer time period.

\subsection{Surface screening of $\mathrm{CH}_{4}$ and $\mathrm{CO}_{2}$}

Screening campaigns performed on the biocover surface for both $\mathrm{CO}_{2}$ and $\mathrm{CH}_{4}$ showed an even distribution of the surface gas emissions. Fig. 7 reports the iso-concentration plots obtained with Surfer 8 
software for $\mathrm{CH}_{4}$ during four screenings performed in different seasons and periods of the study. Due to the duration of the project period no campaigns were performed during the summer months. However, we do not believe that results during the summer would have been very different from the other seasons, especially due to relative stable temperature and moisture conditions within the biocover (confer results in section 5.1). Very low $\mathrm{CH}_{4}$ concentrations were present all over the biocover surface in an average range of 2-3 ppmv, close to the background atmospheric concentration (1.7 ppmv). A modest emission hot spot was identified in the SouthEastern corner during the first campaign (9 ppmv) and also in the following campaign ( $5 \mathrm{ppmv})$. The hot spot had disappeared in following screenings and was not measured again from January 2013 and on. The surface $\mathrm{CO}_{2}$ screenings presented in Fig. 8 show an almost homogeneous distribution, close to the atmospheric concentration (400 ppmv). The average measured values ranged between 400 and 420 ppmv, with a general difference between the Southern and Northern part of the surface of $10 \mathrm{ppmv}$. Several $\mathrm{CO}_{2}$ hot spots were found on the biocover surface in different places from time to time, but no stable and substantial hot spots were identified during the whole study. In general, the two screenings together showed that formation of significant hot spot areas was successfully avoided, probably as a result of a good distribution of the gas from the mixing chamber into the gas distribution layer and further up in the $\mathrm{CH}_{4}$ oxidation layer.

\subsection{Surface fluxes of $\mathrm{CH}_{4}, \mathrm{CO}_{2}$ and tracer gas (HFC-134a)}

Both $\mathrm{CH}_{4}$ and $\mathrm{CO}_{2}$ iso-flux surface plots support the previous presented surface screening observations. For all flux chamber measurement campaigns, $\mathrm{CH}_{4}$ surface emissions show a homogeneous spatial distribution. Examples of the iso-flux distribution for $\mathrm{CH}_{4}$ are represented in Fig. 9 - Graph 1a-1b. Graph 1a refers to the January $25^{\text {th }}, 2013$ campaign and shows an average surface flux of $0.04 \mathrm{~g} \mathrm{C}^{-} \mathrm{CH}_{4} \mathrm{~m}^{-2} \mathrm{~d}^{-1}$, while the second one

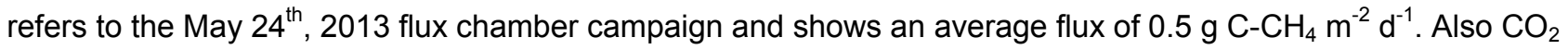
surface fluxes indicate a modest spatial variation, with an average of $50 \mathrm{~g} \mathrm{C}_{-} \mathrm{CO}_{2} \mathrm{~m}^{-2} \mathrm{~d}^{-1}$ for both January $25^{\text {th }}$ and May $24^{\text {th }}$ field measurement (Fig. 9 Graphs 2a and 2b). Minor hot spots were found on the biocover surface in different points from time to time. The presence of these preferential emission points was probably due to changing gas concentrations inside the biocover and to other environmental factors. On the other hand, the 
absence of permanent hot spots through all the flux chamber campaigns demonstrates the homogeneity of emissions and the efficient design of the biocover.

The surface plot of tracer gas fluxes could be considered a precise picture of the distribution quality of the biocover system, and particularly of the gas distribution layer efficiency. Graph 3b in Fig. 9 shows the HFC134a distribution (May $24^{\text {th }}, 2013$ campaign), indicating a modest spatial variation of tracer gas. The average range of tracer gas emission fluxes was found to be between 0.2 and $0.5 \mathrm{~g} \mathrm{C}_{2} \mathrm{H}_{2} \mathrm{~F}_{4} \mathrm{~m}^{-2} \mathrm{~d}^{-1}$, showing good distribution and homogeneous surface emission of gas. By using kriging interpolation of the 50 tracer gas emission measurements over the entire biocover area using the Surfer 8 software, the whole emission of tracer gas was found to be $71 \mathrm{~g} \mathrm{C}_{2} \mathrm{H}_{2} \mathrm{~F}_{4} \mathrm{~d}^{-1}$, which is about $105 \%$ of the tracer gas loading rate $\left(68 \mathrm{~g} \mathrm{C}_{2} \mathrm{H}_{2} \mathrm{~F}_{4} \mathrm{~d}^{-1}\right)$. This shows that the tracer gas experiment had reached stationarity at day 12 of the test, and that all loaded gas was finally leaving the biocover system as surface emissions.

\subsection{Spatial evaluation of pore gas composition in biocover}

The variable composition of the inlet gas could theoretically affect the biocover system stability and efficiency. Vertical 2D gas profiles of the biocover (Eastern part) showed an almost constant distribution and concentration of the analysed gases $\left(\mathrm{CH}_{4}, \mathrm{CO}_{2}\right.$ and $\left.\mathrm{O}_{2}\right)$ even with different inlet gas and atmospheric pressure conditions. The average concentration of studied gases $\left(\mathrm{CH}_{4}, \mathrm{O}_{2}\right.$ and $\left.\mathrm{CO}_{2}\right)$ into the compost pore volume is represented in Fig. 10. It should be noticed that the kriging interpolation used by the contouring program gives erroneous interpolation close to the biocover surface due to very steep gradients. $\mathrm{CH}_{4}$ and $\mathrm{O}_{2}$ vertical gas profiles showed the same trend with higher concentrations close to the gas distribution layer and lower close to the biocover surface. The bottom concentration of $\mathrm{CH}_{4}$ ranged between 3 and $5 \%$ vol., with a final surface concentration after methanotrophic bacteria activity of about $0 \%$ vol. (Fig. 10a). $\mathrm{O}_{2}$ is also consumed both during compost respiration and $\mathrm{CH}_{4}$ oxidation with a decreased from $6 \%$ vol. at $120 \mathrm{~cm}$ depth to $1 \%$ vol. at $20 \mathrm{~cm}$ depth (Fig. 10c). The presence of $\mathrm{O}_{2}$ and its homogeneous distribution in the biocover is very important since $\mathrm{O}_{2}$ is normally the limiting factor for methanotrophic processes. Since the inlet gas contained significant quantities of $\mathrm{O}_{2}$, the biocover was not only loaded by atmospheric $\mathrm{O}_{2}$ diffusion from the top, but also from below due to $\mathrm{O}_{2}$ 
presence in the inlet gas itself. This is different from traditional biocover systems, which are loaded by a more pure LFG not containing $\mathrm{O}_{2}$. The $\mathrm{CO}_{2}$ concentration increased from about $12 \%$ vol. at the bottom to about $18-10$ \%vol. at the top of the biocover $\mathrm{CH}_{4}$ oxidation layer (Fig. 10b). This indicate that $\mathrm{CH}_{4}$ oxidation was taking place at the bottom of the $\mathrm{CH}_{4}$ oxidation layer and probably already in the gas distribution layer. The general trend of the three gases clearly showed that methanotrophic bacteria were active in the system and that $\mathrm{CH}_{4}$ and $\mathrm{O}_{2}$ were consumed and $\mathrm{CO}_{2}$ was generated.

\subsection{Evaluation of gas distribution by the tracer gas experiment}

The HFC-134a concentration in the mixing chamber was constantly monitored during the whole tracer gas test campaign duration to guarantee a constant flux of the tracer gas in the biocover distribution system and a constant tracer gas concentration (about $82 \mathrm{ppmv}$ ). The concentration of tracer gas (HFC-134a) in the mixing chamber is represented by the red lines in Fig. 11 and shows a stable and constant trend of the gas, with natural fluctuations between 80 and 84 ppmv (0.97-1.03 normalized).

The breakthrough curve of the tracer gas for each sampling port has been drawn by plotting HFC-134a concentrations (ppmv) and time (hours). The normalized concentration (from 0 to 1) has then been calculated by dividing the point concentrations for the maximum concentration at saturation (82 ppmv). Data collected from the two tracer gas injection campaigns and plotted as breakthrough curve gave interesting results regarding the gas distribution in the biocover.

During the first tracer gas test campaign (December $5^{\text {th }}-9^{\text {th }}, 2012$ ), the stationary concentration of 82 ppmv was reached for all ports installed in the Southern sampling transect of the biocover. The stationary concentration level was achieved for all Southern sampling ports between 50 and 100 hours from the initiation of HCF-134a injection. The stationary concentration level was also reached in the Northern sampling transect of the biocover for $D(-100 \mathrm{~cm}$ deep $)$ and $B(-50 \mathrm{~cm}$ deep) ports but never for ports $A(-20 \mathrm{~cm})$ due to the premature termination of the campaign (data not shown). During the second tracer gas test campaign (May $16^{\text {th }}-27^{\text {th }}, 2013$ ), tracer gas stationarity was reached in both the Southern and Northern sampling transects of the biocover and at all depths. Sampling ports placed in Southern transect at all depths (gas distribution layer and $\mathrm{CH}_{4}$ oxidation layer) and ports placed in the Northern transect gas distribution layer reached a stable concentration level 
between 50 and 100 hours from the injection start (Fig. 11a and b). Sampling ports placed in the Northern transect in the biocover $\mathrm{CH}_{4}$ oxidation layer reached a stationary conformation between 100 and 200 hours after tracer gas injection start (Fig. 11b).

In general, the tracer gas experiments gave steep breakthrough curves with similar breakthrough times of sampling ports from the Southern transect independent of the distance from the inlet point. The breakthrough time was around 10 hours in the ports placed in the gas distribution layer and $10-20$ hours in the $\mathrm{CH}_{4}$ oxidation layer. This shows an efficient and even delivery of gas in the un-slotted gas delivery pipe and the first part of the slotted gas distribution pipes. Breakthrough curves in ports from the Northern transect showed, however, longer breakthrough times indicating a slower distribution of gas to the Northern part of the biocover. For the Northern transect, breakthrough time was around 20-30 hours in the ports placed in the gas distribution layer and 30-60 hours in ports placed in the $\mathrm{CH}_{4}$ oxidation layer.

\section{Conclusions}

Newer landfills are often receiving waste with lower organic contents leading to a lower, but still significant gas generation. Such landfills are often lined but not equipped with a gas extraction system due to the low expected gas generation. In such cases, the generated gas is often emitted to a large extent through the leachate wells directly into the atmosphere. In order to evaluate the possibility of mitigating the $\mathrm{CH}_{4}$ emission by a semi-passive system, an innovative $500 \mathrm{~m}^{2}$ pilot-scale biocover system was established at the AV Miljø Landfill, Denmark. In this system, gas was collected from leachate wells and fed into an established biocover system, where the $\mathrm{CH}_{4}$ contained in the collected gas was microbially oxidized. The system was equipped with a new-developed gas distribution system consisting of a "zig-zag shaped" interface between the compost layer and the gas distribution layer. The interface was easily constructed manually in a few days using shovels. There were indications on that the interface improved the discharge of accumulating water, which otherwise could have led to gas blockage. Additional testing of the system is however needed to fully document the functionality of the developed novel design idea.

The collected gas from the leachate wells was significantly mixed with atmospheric air, which had intruded 
the collection sheds or other locations in the leachate collection system. This created a biocover system with supply of $\mathrm{O}_{2}$ not only by diffusion from the atmosphere into the cover, but also as part of the gas load.

Relatively even gas distribution was achieved in a $500 \mathrm{~m}^{2}$ biocover system by use of the new-developed gas distribution system. Even gas distribution is a prerequisite for obtaining an efficient biocover without the formation of emission hot spots on the biocover surface. The even gas distribution was indicated by $\mathrm{CH}_{4}$ and $\mathrm{CO}_{2}$ concentration screenings, and further documented by flux measurements at the biocover surface and by the performance of a tracer gas experiment. The tracer gas experiment showed equal distribution of gas to different parts of the biocover by the un-slotted gas distribution pipe and even distributed emissions of tracer gas over the biocover area. The tracer gas experiment also showed that the gas travel time in the gas distribution system to the Northern part of the biocover systems was longer than to the Southern part, which was located closer to the gas inlet.

By installation of moisture and temperature probes it was documented that significantly elevated temperatures were achieved in the biocover due to self-heating $\mathrm{CH}_{4}$ oxidation and compost respiration processes. Moisture content logging in several depths of the biocover system indicated that the system was able to discard excess precipitation.

The biocover system was monitored over a period of several months after the finalization of the biocover system. The functionality of compost-based biocover systems may change over time due to consolidation process of the compost layer as a result of continuous maturing of the compost. Additional studies are therefore needed to address potential changes of system functionality with time.

\section{Acknowledgments}

This research was funded by the AV Miljø disposal site and the Technical University of Denmark. We would like to acknowledge Christian Pilegaard Jespersen and Stefan Emil Danielsson for performing the initial tracer gas release experiments (November and December 2013), and Hans Henrik Jørgensen Halvbjørn, Monika Margrethe Skadborg, and Rune Skovsø Møller for performing the flux chamber campaigns. We would like to acknowledge Stefan Trapp and Björg Árnadóttir for characterizating the biocover vegetation, and Torben Dolin for his contributions to the graphical work. 


\section{References}

Bogner, J., Pipatti, R., Hashimoto, S., Diaz, C., Mareckova, K., Diaz, L., Kjeldsen, P., Monni, S., Faaij, A., Qingxian, G., Tianzhu, Z., Mohammed, A.A., Sutamihardja, R.T.M., Gregory, R., 2008. Mitigation of global greenhouse gas emissions from waste: conclusions and strategies from the intergovernmental panel on climate change (IPCC) fourth assessment report. Working group III (Mitigation). Waste Manage. Res. 26 (1), 11-32.

Christophersen, M., Kjeldsen, P., 2001. Lateral gas transport in soil adjacent to an old landfill: Factors governing gas migration. Waste Management \& Research 19 (2), 144-159.

Coccia, C. J. R., Gupta, R., Morris, J., McCartney, J.S., 2013. Municipal solid waste landfills as geothermal heat sources. Renewable \& Sustainable Energy Reviews 19, 463-474.

Czepiel, P.M., Shorter, J.H., Mosher, B., Allwine, E., McManus, J.B., Harriss, R.C., Kolb, C. E., Lamb, B.K., 2003. The influence of atmospheric pressure on landfill methane emissions. Waste Management 23, 593598.

Fredenslund, A.M., Scheutz, C., Kjeldsen, P., 2010. Tracer method to measure landfill gas emissions from leachate collection systems. Waste Management, 30, 2146-2152.

Gebert, J. \& Gröngröft, A., 2012. Requirements on gas permeability of gas distribution and methane oxidation layers in biological methane oxidation systems. Intercontinental Landfill Research Symposium 2012, Luleå, Sweden, 25-27 June 2012.

Geck, C., Gebert, J., Scharff, H., Pfeiffer, E-M., 2012. Heterogeneous gas distribution within a biocover designed for methane oxidation. Intercontinental Landfill Research Symposium 2012, Luleå, Sweden, 25-27 June 2012.

Kjeldsen, P., Scheutz, C., 2014. Reduction of methane emission from landfills using bio-mitigation systems from lab test to full scale implementation. In: Proceedings Euroasia 2014 Waste Management Symposium, 28-30 April 2014, Istanbul, Turkey. 
Kjeldsen, P. and Scheutz, C., 2011. Evaluating gas emissions from landfills - which methodologies can be used? Proceedings Sardinia 2011, Thirteenth International Waste Management and Landfill Symposium S. Margherita di Pula, Cagliari, Italy; 3 - 7 October 2011 @2011 by CISA Publisher, Italy

Kjeldsen, P., Scheutz, C., Samuelsson, J., Petersen, P.H. Jørgensen, J.H.B., 2009. Establishing a biocover system for mitigating methane emissions from and old unlined landfill-baseline studies and biocover construction. In: Sardinia 2009, Twelfth International Waste Management and Landfill Symposium, 5-9 October, Sardinia, Italy. Proceedings.

Pedersen, G.B. (2010). Processes in a compost based landfill biocover; methane emission, transport and oxidation. Ph.D. thesis. Department of Environmental Engineering, Technical University of Denmark.

Roncato, C. D. and Cabral, A. R. (2011). Evaluation of methane oxidation efficiency of two biocovers: field and laboratory results. Journal of Environmental Engineering, 138(2):164-173.Sadasivam, B. Y. and Reddy, K. R. (2014). Landfill methane oxidation in soil and bio-based cover systems: a review. Reviews in Environmental Science and Bio/Technology, 13(1):79-107.

Scheutz, C., Cassini F., De Schoenmaeker, J., Kjeldsen, P., 2017. Mitigation of methane emissions in a pilotscale biocover system at the AV Miljø Landfill, Denmark: 2. Methane oxidation. Waste Management, XX, XX$\mathrm{xx}$.

Scheutz, C., Pedersen, R.B., Petersen, P.H., Jørgensen, J.H.B., Ucendo, I.M.B., Mønster, J.G.,Samuelsson, J. \& Kjeldsen, P., 2014. Mitigation of methane emission from an old unlined landfill in Klintholm, Denmark using a passive biocover system, Waste Management, 34, 1179-1190.

Scheutz, C., Fredenslund, A. M., Chanton, J., Pedersen, G. B., Kjeldsen, P., 2011a. Mitigation of methane emission from Fakse landfill using a biowindow system. Waste Management, 31(5), 1018-1028.

Scheutz, C., Samuelsson, J., Fredenslund, A. M., Kjeldsen, P., 2011b. Quantification of multiple methane emission sources at landfills using a double tracer technique. Waste Management, 31(5), 1009-1017.

Scheutz, C., Fredenslund, A. M., Nedenskov, J., Samuelsson, J., Kjeldsen, P., 2011d. Gas production, composition and emission at a modern disposal site receiving waste with a low-organic content. Waste Management , 31(5), 946-955. 
Scheutz, C.,. Bogner, J., De Visscher, A., Gebert, J., Hilger, H., Huber-Humer, M., Kjeldsen, P., and Spokas, K., 2009. Processes and technologies for mitigation of landfill gas emissions by microbial methane oxidation. Waste Management \& Research, 27(5), 409-455.

Scheutz, C., Pedersen, G.B., Costa, G., Kjeldsen, P., 2009. Biodegradation of methane and halocarbons in simulated landfill biocover systems containing compost materials. Journal of Environmental Quality 38, $1363-1371$.

Scheutz, C., Dote, Y., Fredenslund, A.M., Mosbæk, H., Kjeldsen P., 2007. Attenuation of fluorocarbons released from foam insulation in landfills. Environ. Sci. Technol. 41, 7714-7722.

Scheutz, C., Mosbæk, H., Kjeldsen, P., 2004. Attenuation of methane and volatile organic compounds in landfill soil covers. Journal of Environmental Quality, 33, 61-71.

Tetreault, P. Cabral A.R., 2013. Non-uniform distribution of biogas under a biocover due to capillary barrier effect: case studies. Geo Montreal, 2013. 
Table 1. The gas composition (\%vol.) measured in the inlet mixing chamber feeding the biocover system. . The gas composition was measured using a field instrument (IR Device Biogas 5000) and by continuous analysis using a permanently installed methane sensor.

\begin{tabular}{|c|c|c|c|c|c|}
\hline \multirow{2}{*}{ Date } & \multicolumn{4}{|c|}{ IR Device - Biogas 5000} & \multirow{2}{*}{$\frac{\text { Sensor }}{\mathrm{CH}_{4}}$} \\
\hline & $\mathrm{CH}_{4}$ & $\mathrm{CO}_{2}$ & $\mathrm{O}_{2}$ & $\mathrm{~N}_{2}$ & \\
\hline $30 / 072012$ & 4.8 & 5.1 & 12.9 & 77.2 & 4.2 \\
\hline 02/08 2012 & 10.6 & 7.8 & 8.1 & 73.5 & 9.6 \\
\hline 03/08 2012 & 6.9 & 6.2 & 10.5 & 76.4 & 5.7 \\
\hline 07/08 2012 & 6.3 & 5.4 & 12.8 & 75.5 & 5.7 \\
\hline 07/09 2012 & 6.3 & 7.0 & 11.5 & 75.2 & 4.0 \\
\hline 19/09 2012 & 2.0 & 3.3 & 17.2 & 77.5 & 1.3 \\
\hline 23/09 2012 & 1.2 & 2.2 & 17.9 & 78.7 & 1.3 \\
\hline 26/09 2012 & 2.8 & 4.3 & 13.7 & 79.2 & 1.3 \\
\hline 28/09 2012 & 0.7 & 2.7 & 16.9 & 79.7 & 1.3 \\
\hline 03/10 2012 & 6.6 & 6.9 & 12.2 & 74.3 & 5.2 \\
\hline $10 / 102012$ & 8.2 & 6.5 & 11.5 & 73.8 & 7.1 \\
\hline $16 / 102012$ & 6.5 & 5.7 & 13.4 & 74.4 & 10.2 \\
\hline $24 / 102012$ & 12.8 & 10.7 & 5.4 & 71.1 & 12.3 \\
\hline $31 / 102012$ & 5.3 & 5.4 & 14.0 & 75.3 & 4.4 \\
\hline $07 / 112012$ & 6.0 & 5.5 & 13.4 & 75.1 & 5.7 \\
\hline $14 / 112012$ & 7.9 & 7.3 & 10.0 & 74.8 & 7.2 \\
\hline $20 / 112012$ & 7.7 & 6.7 & 10.7 & 74.9 & 6.5 \\
\hline $28 / 112012$ & 8.8 & 7.6 & 11.0 & 72.6 & 7.1 \\
\hline $08 / 122012$ & 6.8 & 5.9 & 12.4 & 74.9 & 5.5 \\
\hline 11/03 2013 & 10.7 & 8.0 & 8.9 & 72.4 & 6.1 \\
\hline 09/04 2013 & 8.6 & 6.5 & 12.7 & 72.2 & 7.2 \\
\hline $11 / 042013$ & 9.6 & 7.0 & 10.2 & 73.2 & 7.8 \\
\hline $18 / 042013$ & 5.8 & 5.0 & 16.2 & 75.3 & 6.9 \\
\hline $02 / 052013$ & 6.8 & 6.7 & 11.0 & 75.5 & 5.9 \\
\hline $24 / 052013$ & 6.8 & 7.5 & 10.5 & 75.2 & 5.4 \\
\hline Average & 6.7 & 6.1 & 12.2 & 76.1 & 5.8 \\
\hline
\end{tabular}




\section{Figures}

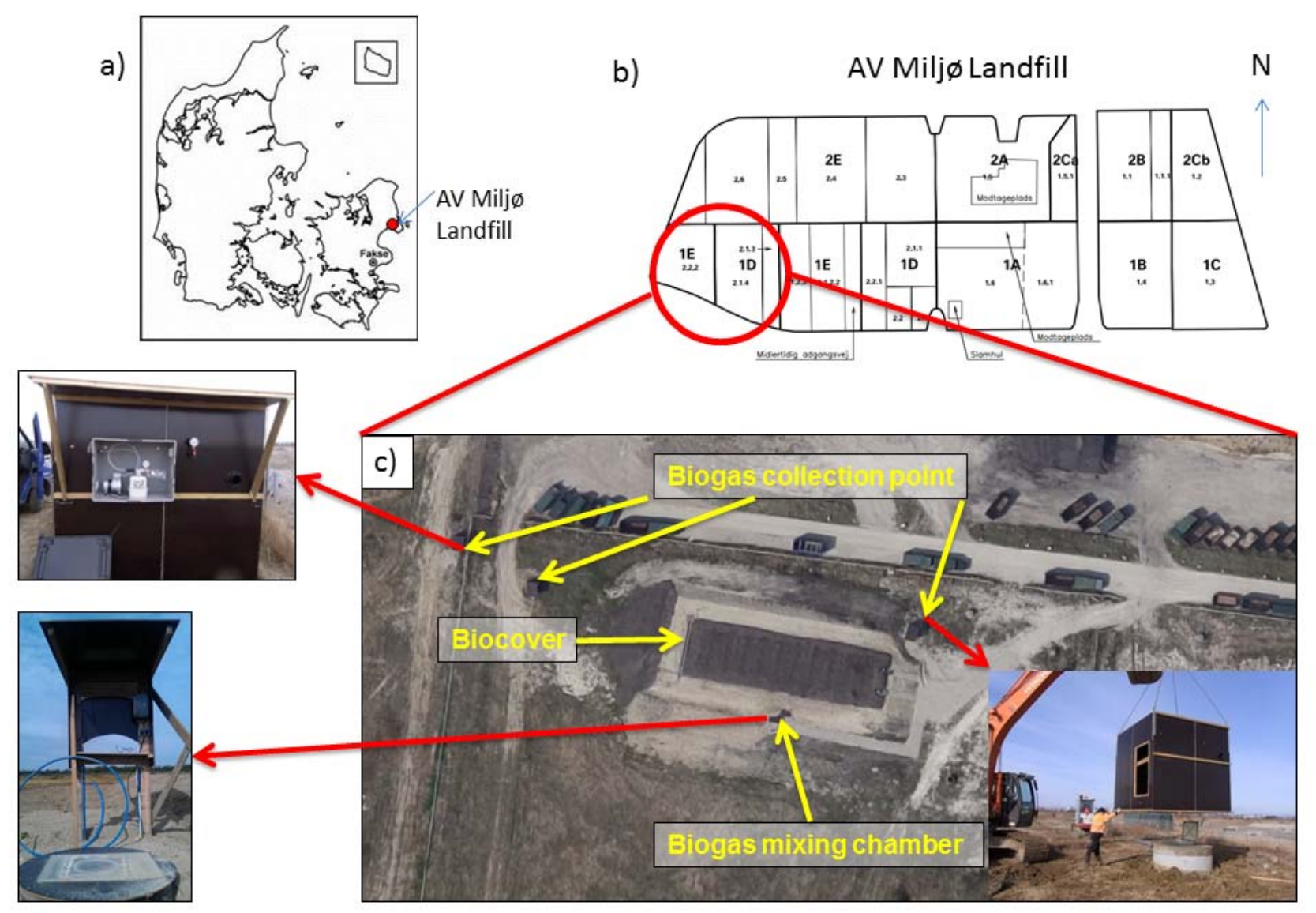

Fig. 1. The test site. a) Location of AV Miljø, b) Map of AV Miljø Landfill with location of the test site, c) Sketch of the pilot biocover systems showing the locations of the three gas emitting leachate wells, the mixing chamber and the biocover area. 


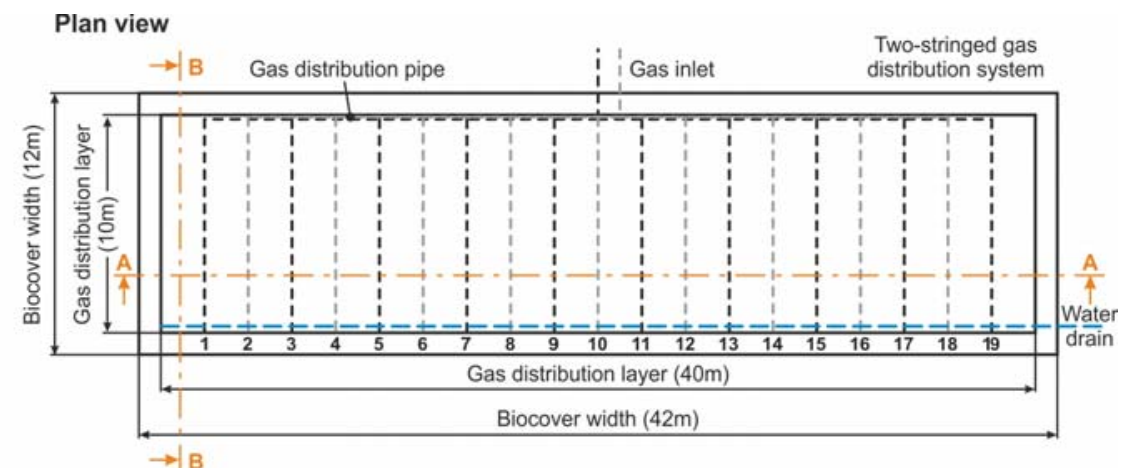

Section A-A

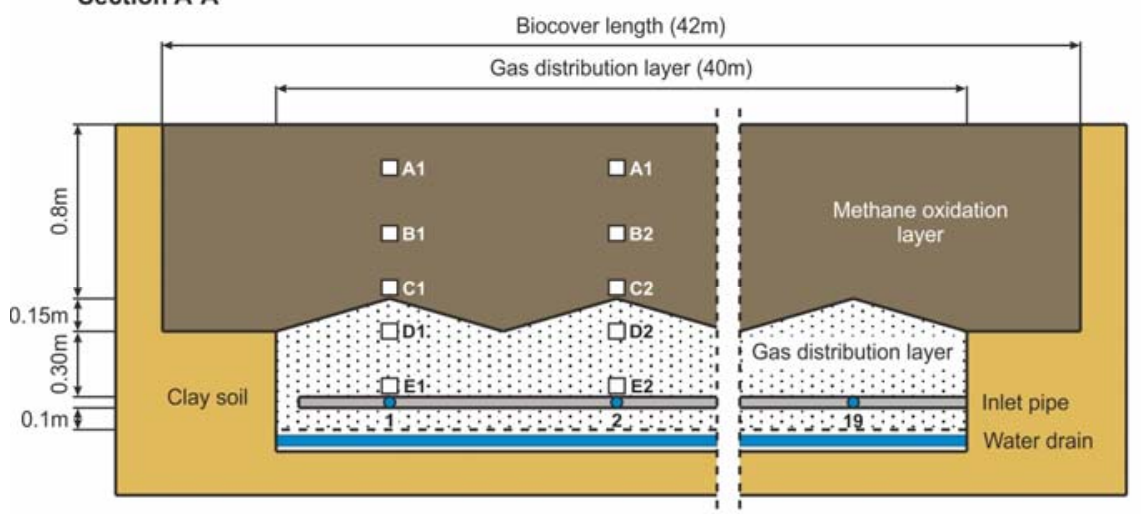

Section B-B

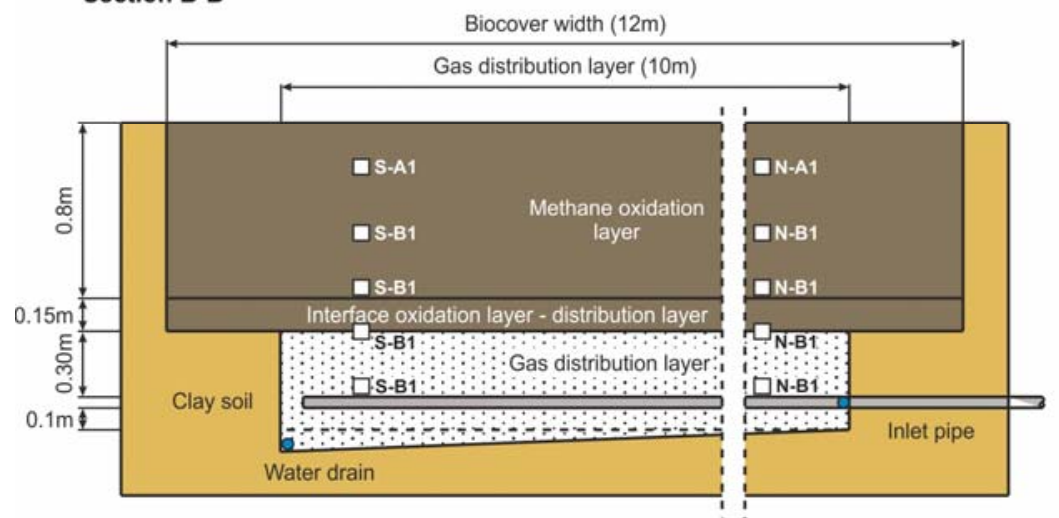

Fig. 2. a) Plan view of biocover showing the gas distribution system with 19 slotted gas pipes connected to an un-slotted delivery pipe, b) Sectional view of biocover showing the zig-zag shaped interface between the $\mathrm{CH}_{4}$ oxidation layer and the gas distribution layer, c) Sectional view of biocover showing water draining and gas distribution pipes. Locations of selected gas sampling ports in the two transects are indicated in sections A-A' and B-B'. 


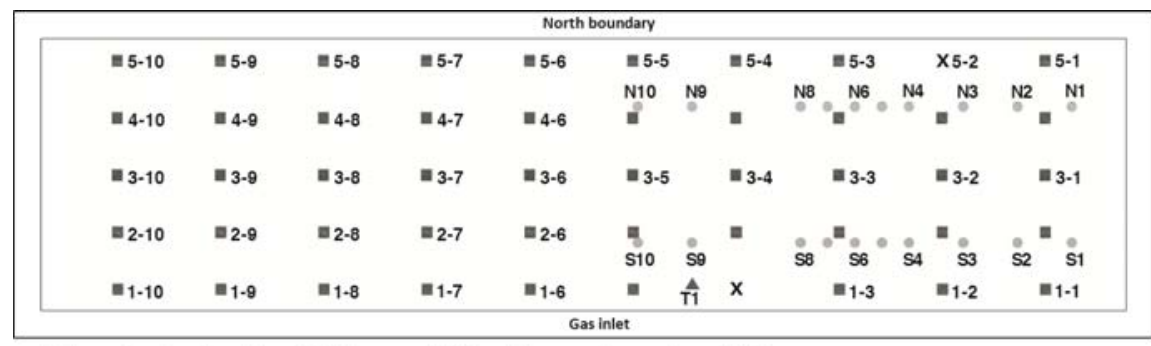

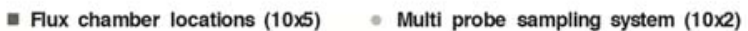

$X$ Flux chamber location and compost sampling site_ Temperature and moisture probes

Fig. 3. Map of the biocover monitoring system showing locations of flux chamber measurements, multi probe samplings locations, temperature/moisture probes and compost sampling sites.

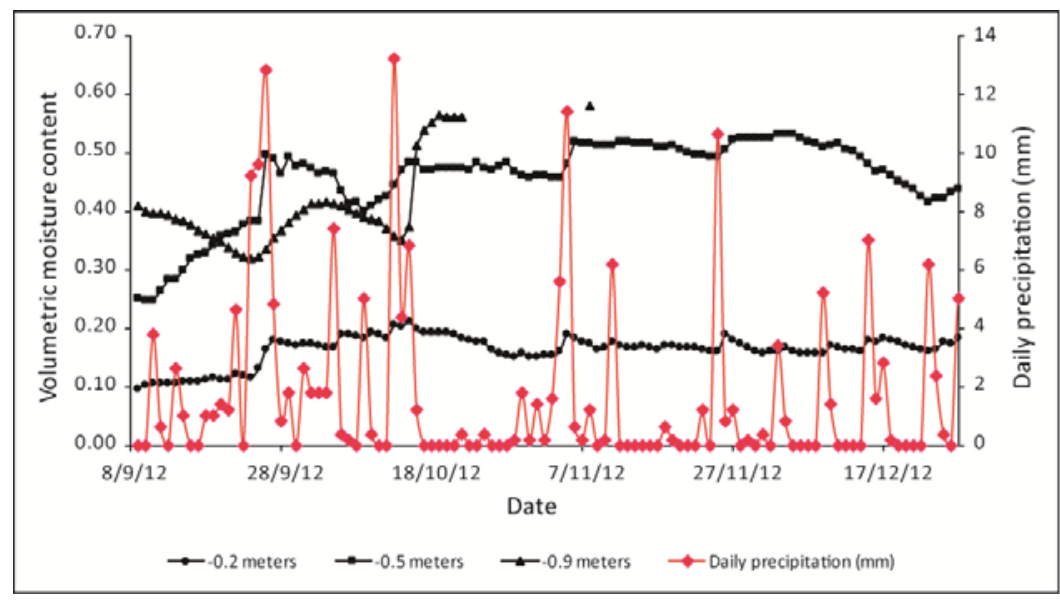

Fig. 4. Moisture content $\left(\mathrm{m}^{3}\right.$ water $/ \mathrm{m}^{3}$ biocover volume) in selected depths of the biocover. Local values for daily precipitation are also shown. 


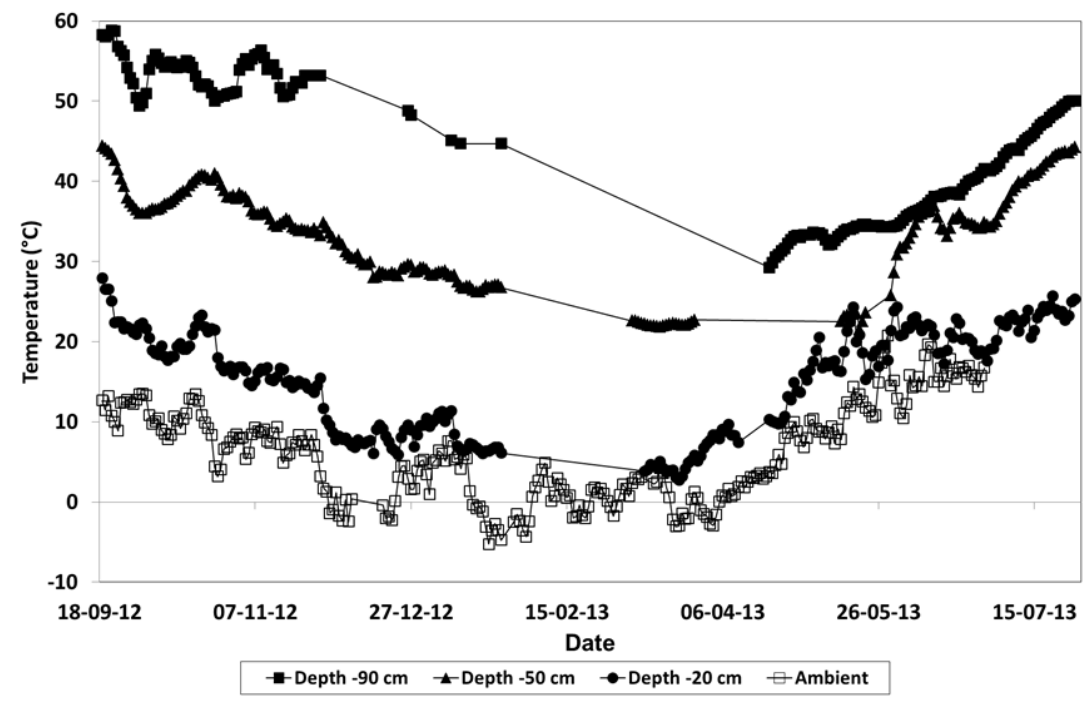

Fig. 5. Temperatures measured in biocover at different depth in comparison to ambient temperature for the period September $18^{\text {th }}, 2012$ until July $15^{\text {th }}, 2013$.

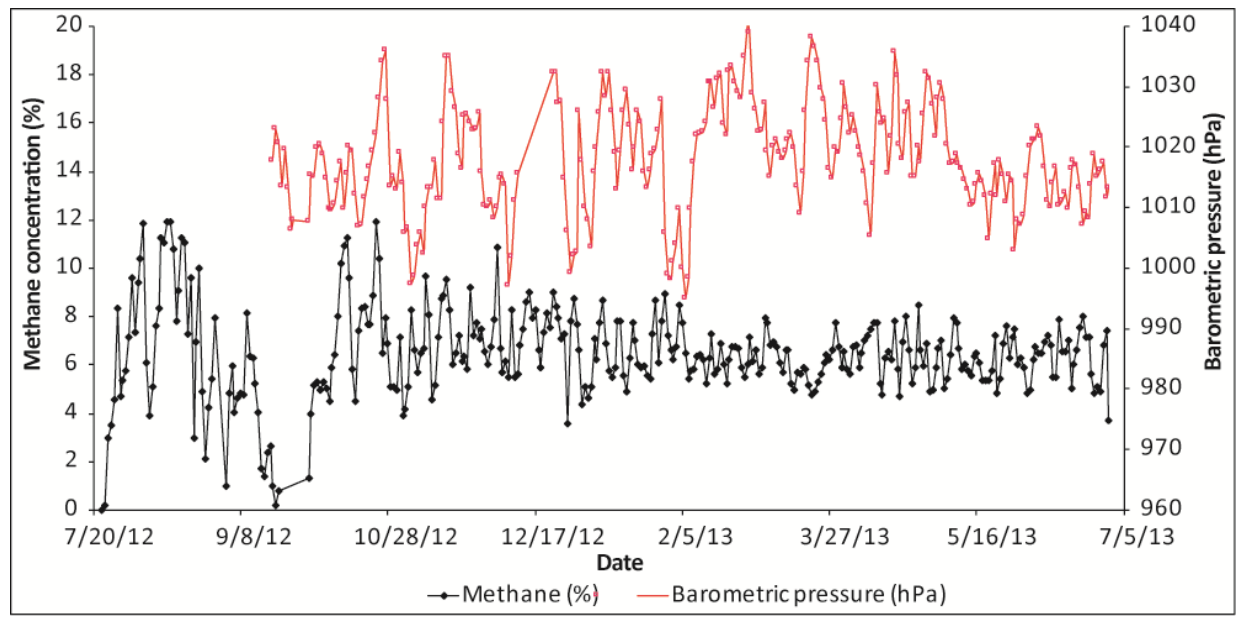

Fig. 6. Concentration of $\mathrm{CH}_{4}$ (in \% vol.) in the mixing chamber during the experimental period. Also the recorded barometric pressure (in $\mathrm{hPa}$ ) is shown. 

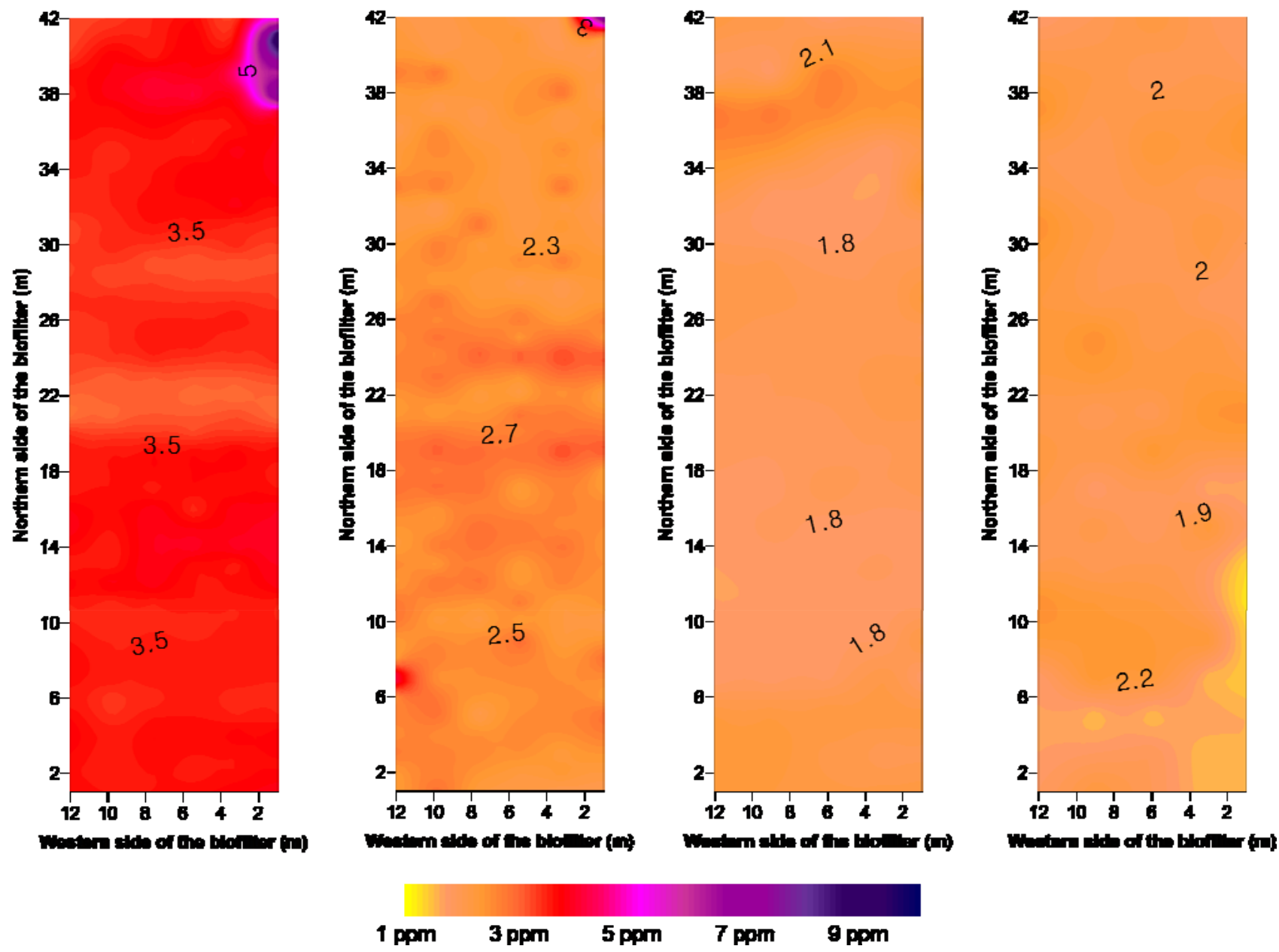

Fig. 7. Iso-concentration plots for $\mathrm{CH}_{4}$ on the biocover surface from 4 different screening campaigns, carried out on November $28^{\text {th }}, 2012$, December $4^{\text {th }}, 2012$, April $11^{\text {th }}, 2013$, and May $5^{\text {th }}, 2013$. Concentrations are expressed in ppmv. 

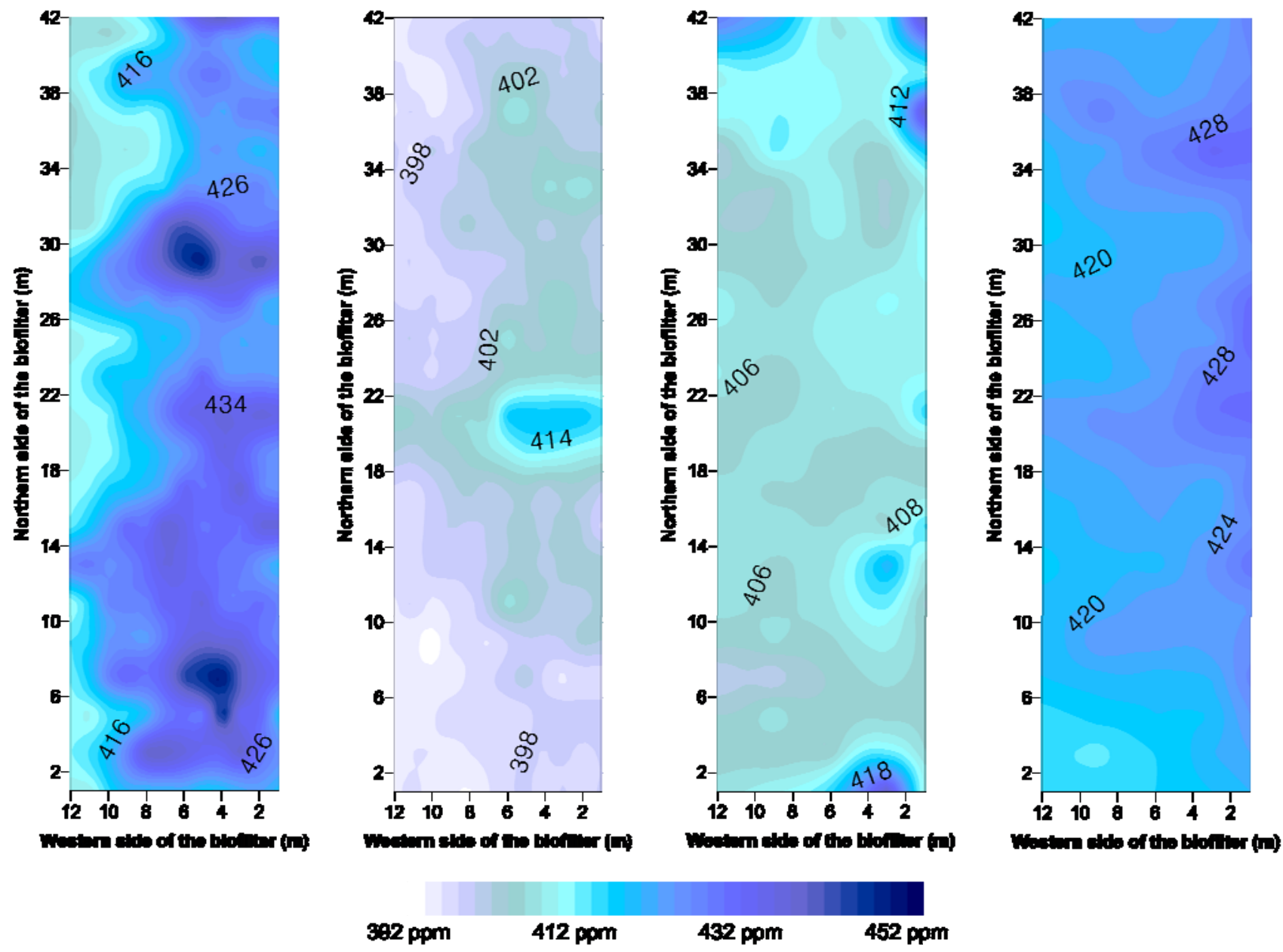

Fig. 8. Iso-concentration plots for $\mathrm{CO}_{2}$ on the biocover surface from 4 different screening campaigns, carried out on (a) November $28^{\text {th }}, 2012$, (b) December $4^{\text {th }}, 2012$, (c) April $11^{\text {th }}, 2013$ and (d) May $5^{\text {th }}, 2013$. Concentrations are expressed in ppmv. 


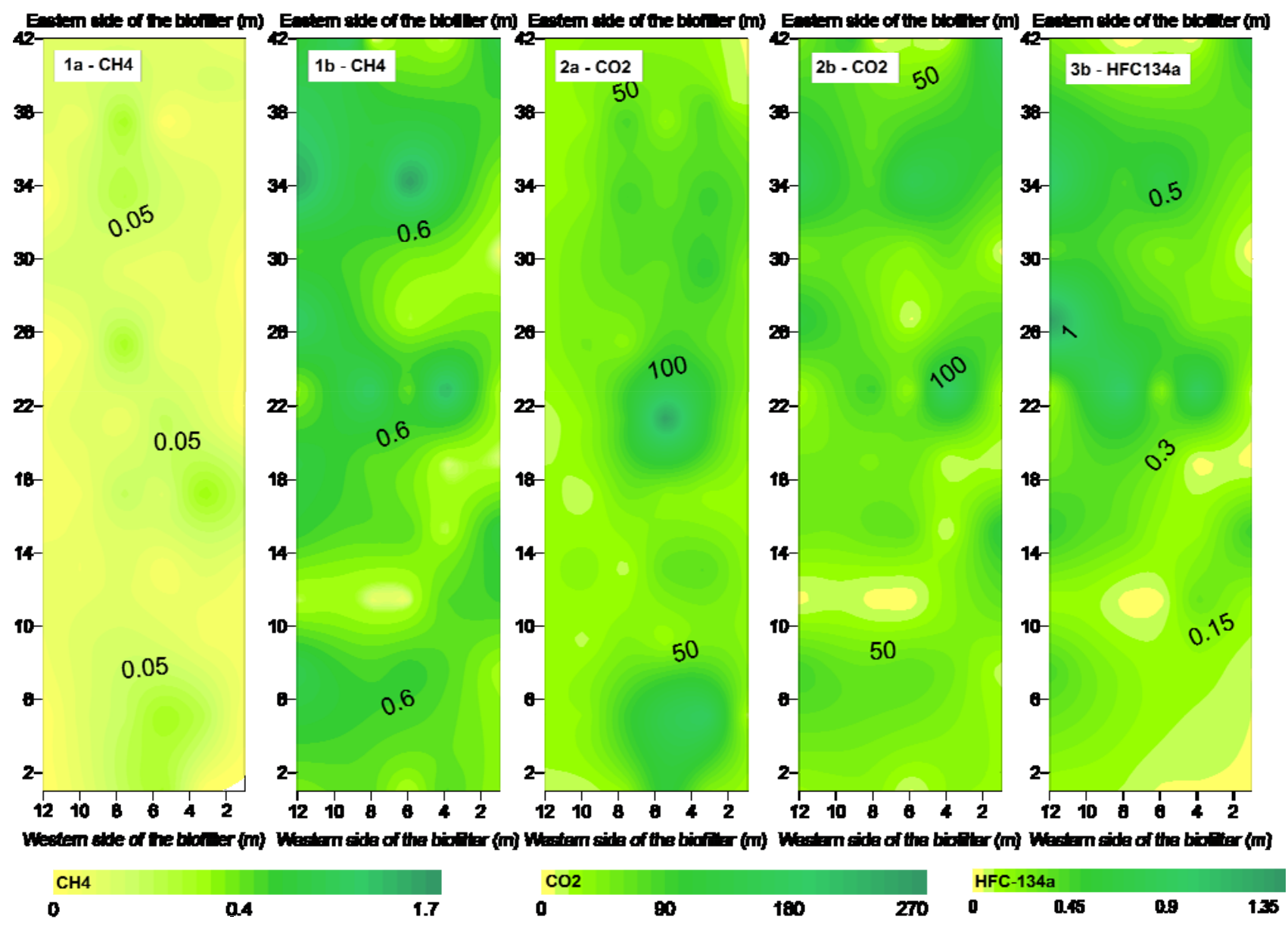

Fig. 9. Iso-flux plots for $\mathrm{CH}_{4}$ (1), $\mathrm{CO}_{2}$ (2) and HFC-134a (3) on the biocover surface from 2 different flux chamber campaigns, carried out on (a) January $25^{\text {th }}, 2013$ and (b) May $24^{\text {th }}, 2013$. Surface fluxes are expressed in $\mathrm{g} \mathrm{C} \mathrm{m}^{-}$ ${ }^{2} \mathrm{~d}^{-1}$ for $\mathrm{CH}_{4}$ and $\mathrm{CO}_{2}$ and in $\mathrm{g} \mathrm{C}_{2} \mathrm{H}_{2} \mathrm{~F}_{4} \mathrm{~m}^{-2} \mathrm{~d}^{-1}$ for the tracer gas (HFC-134a). 

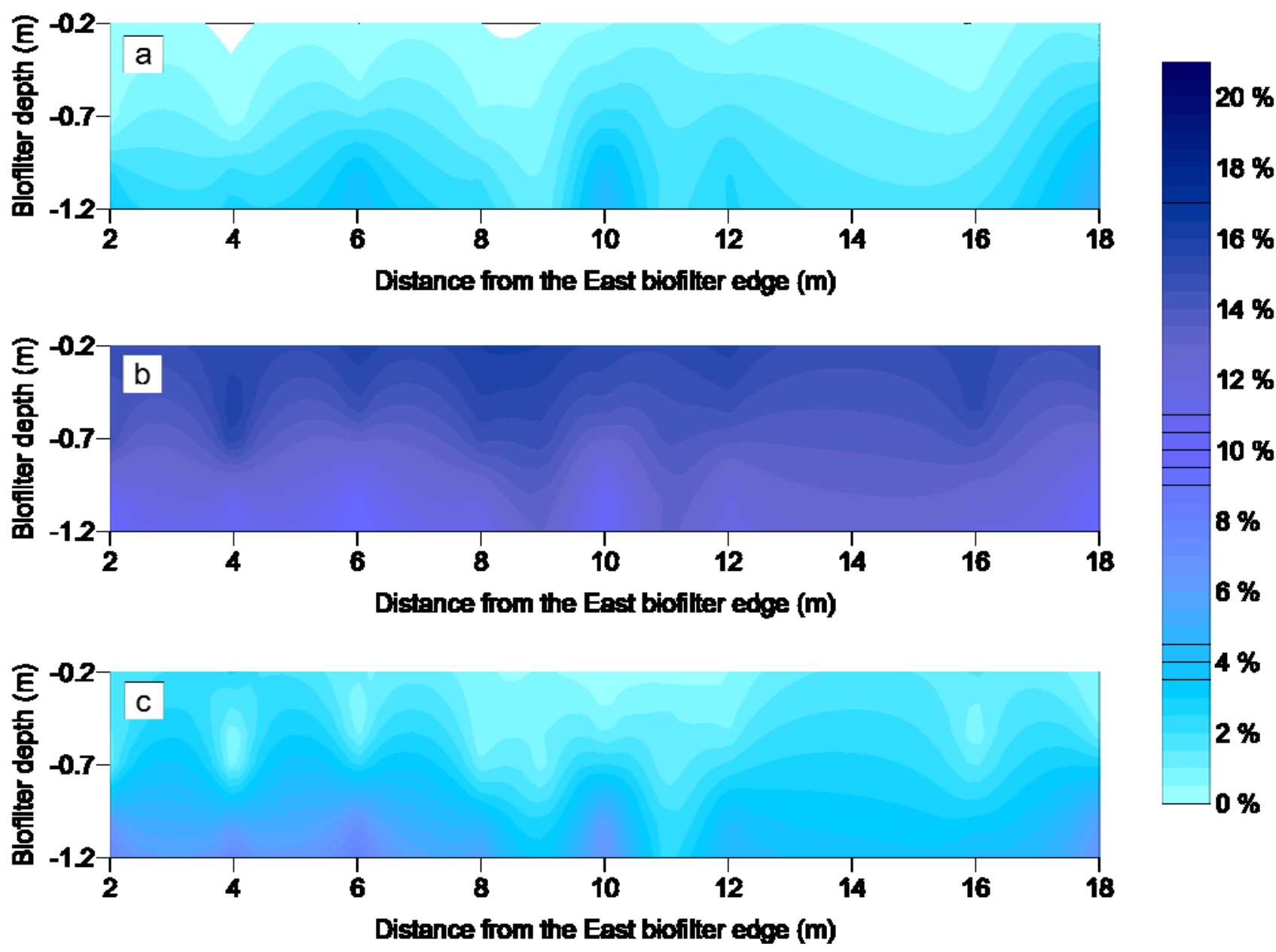

Fig. 10. Gas composition (a: $\mathrm{CH}_{4}$, b: $\mathrm{CO}_{2}, \mathrm{C}: \mathrm{O}_{2}$ ) in the pore gas of the biocover as a function of biocover depth and location from east biofilter edge as measured in the southern horizontal multi gas probe system. 
a)

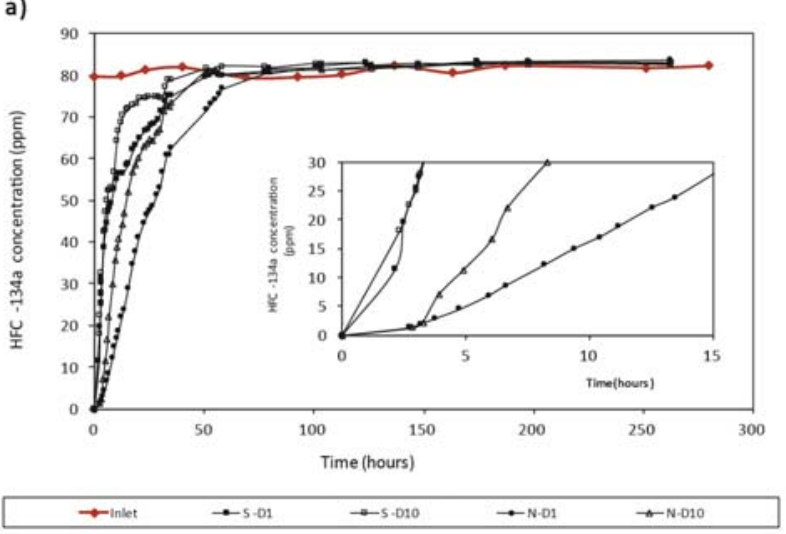

b)

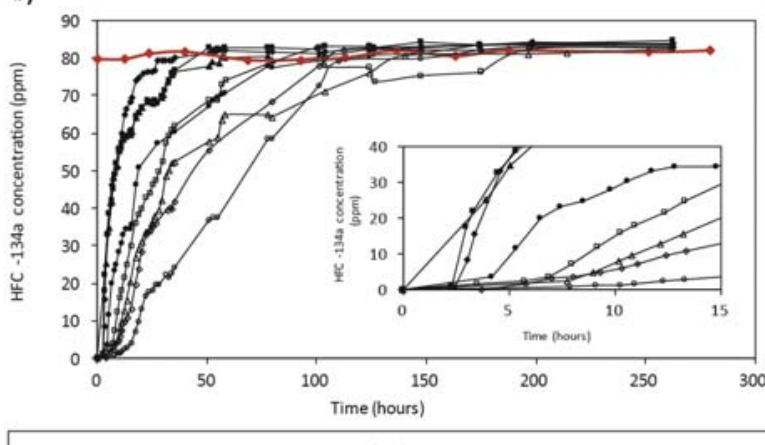

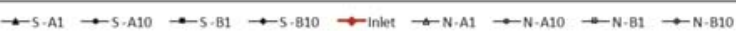

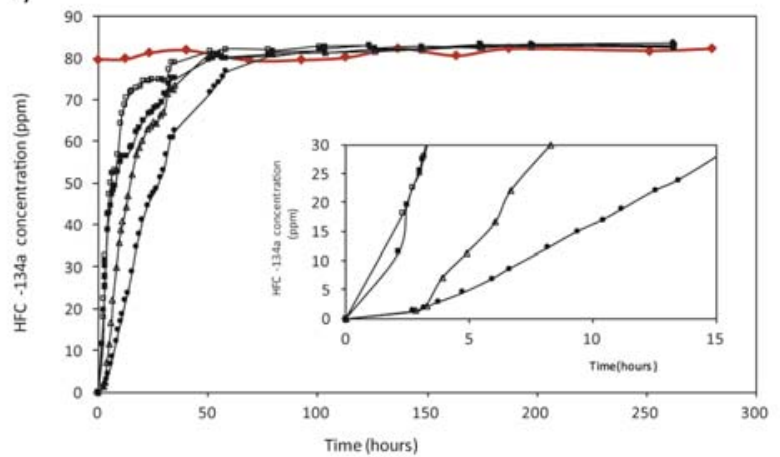

$\rightarrow \rightarrow$ inet $\rightarrow-5 \cdot 01 \quad \rightarrow-5 \cdot 010 \quad \rightarrow-N-01 \quad \rightarrow-N \cdot 10$

b)

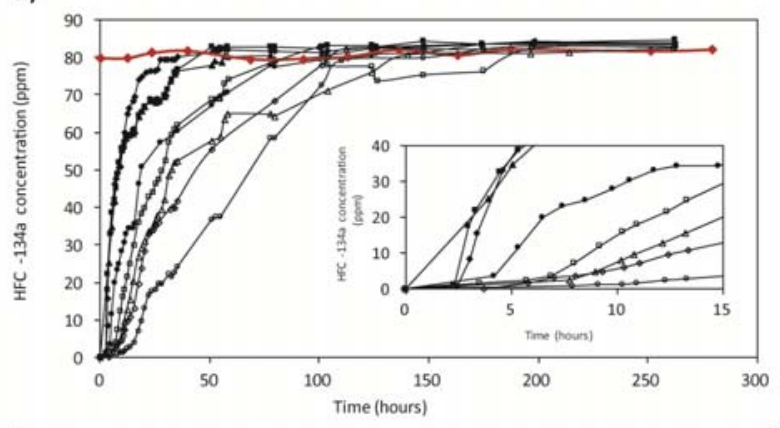

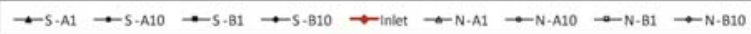

Fig. 11. Concentrations of tracer gas (HFC-134a) in the mixing chamber representing influent and in gas probes placed in the gas distribution layer (a) and the $\mathrm{CH}_{4}$ oxidation layer (b) at different locations in the Southern and Northern transects. 